\title{
Pengaruh Gaya Kepemimpinan Terhadap Kinerja Pegawai dengan Motivasi dan Disiplin Kerja Sebagai Variabel Intervening Pada Dinas Pekerjaan Umum dan Perumahan Rakyat Provinsi Jambi
}

\author{
${ }^{1}$ Pantun Bukit, ${ }^{2}$ Fakhrul Rozi Yamali, ${ }^{3}$ Rizki Ananda \\ ${ }^{1}$ Dosen Program Magister Manajemen FE UNBARI, \\ ${ }^{2}$ Dosen Program Magister Manajemen FE UNBARI, \\ ${ }^{3}$ Alumni Program Magister Manajemen FE UNBARI
}

\begin{abstract}
The purpose of this research is to obtain an overview of the leadership style, motivation, discipline, and performance of employees in the Office of Public Works and people's housing of Jambi province; And to know the influence of leadership styles on motivation, work discipline and performance; And to know the influence of leadership styles through motivation and work discipline toward performance. The population in this study was the Office of Public Works and people's housing of Jambi province, amounting to 286 employees. The size or number of samples in this study was determined based on the theory that Slovin developed with a margin error of 5\% obtained as many as 75 people. Analytical techniques using the analysis path, are transmitted by testing $R$ Square and partial and simultaneous hypothesis testing with T-Test and F-Test. Testing path of analysis carried out, obtained the results of the leadership style has an influence on the motivation, work discipline and performance of employees, motivation and work discipline also has an influence on both the performance and Simultaneously, and the leadership style has an influence on performance through motivation and work discipline. This explains that if an organization has a leader with a leadership style that is appropriate for its employees, this will affect the motivation, work discipline, and performance of its employees. Because the right leadership style has a very dominant role in determining the success of an organization, the right leadership style will be able to direct its employees to work optimally in achieving organizational objectives.
\end{abstract}

Keywords: leadership style, motivation, work discipline and performance.

\section{PENDAHULUAN}

Dalam sebuah organisasi, gaya kepemimpinan seorang pemimpin adalah hal yang penting diperhatikan. Kepemimpinan dalam sebuah organisasi dituntut untuk bisa membuat individu-individu dalam organisasi yang dipimpinnya bisa berperilaku sesuai dengan yang diinginkan oleh pemimpin untuk mencapai tujuan organisasi. Maka dari itu seorang pemimpin haruslah bisa memahami perilaku individuindividu di dalam organisasi yang dipimpinnya untuk bisa menemukan gaya kepemimpinan yang tepat bagi organisasinya. Kepemimpinan secara luas yang meliputi proses mempengaruhi untuk menentukan tujuan perusahaan, maka kepemimpinan harus dapat memotivasi perilaku karyawan untuk mencapai tujuan dan mempengaruhi untuk memperbaiki kelompok dan budayanya. Karena keberhasilan dalam gaya kepemimpinan dapat menggerakkan orang lain dalam mencapai tujuan yang telah ditetapkan oleh perusahaan. Oleh karena itu, untuk menjaga kelangsungan operasional perusahaan dalam mencapai tujuannya, maka diperlukan motivasi yang dapat meningkatkan kinerja karyawan dan gaya kepemimpinan yang dapat mendukung karyawan dalam melaksanakan tugas-tugasnya dengan baik.

Beberapa penelitian yang telah dilakukan sebelumnya juga mengungkapkan, jika gaya kepemimpinan berpengaruh terhadap motivasi kerja, diantaranya yaitu penelitian Fitriani dan Mane (2016), Nanda dan Wikansari (2017), dan Rego, Supartha, dan Yasa (2017), dimana Gaya kepemimpinan berpengaruh positif dan signifikan terhadap motivasi kerja. Motivasi menyangkut perilaku manusia dan merupakan sebuah unsur yang vital dalam manajemen. Ia dapat didefinisikan sebagai membuat seseorang menyelesaikan pekerjaan dengan semangat, karena orang itu ingin melakukannya. Tugas manajer atau pemimpin adalah menciptakan kondisi-kondisi kerja yang akan membangkitkan dan memelihara keinginan untuk bersemangat. Motivasi diri sendiri berasal dari keinginan yang keras untuk mencapai suatu tujuan tertentu.Tidak peduli kesulitan-kesulitan apapun yang harus diatasi (Terry, dan Rue, 2010).

Senada dengan pendapat Hersey dan Blanchard dalam Sedarmayanti (2011) yang menyatakan motivasi cendrung menurun kekuatannya apabila terpenuhi atau terhambat pemenuhannya. Pendapat Hersey dan Blanchard tersebut menyatakan bahwa apabila motivasi tidak diberikan kepada bawahan akan mengalami penurunan hasil kinerjanya, dan apabila motivasi diberikan, maka hasil kinerjanya lebih baik atau mengalami kekuatan yang tinggi. Beberapa hasil penelitian juga mengungkapkan bahwa kinerja 
Rizki Ananda et al, Pengaruh Gaya Kepemimpinan Terhadap Kinerja Pegawai dengan Motivasi dan Disiplin Kerja Sebagai Variabel Intervening Pada Dinas Pekerjaan Umum dan Perumahan Rakyat Provinsi Jambi

pegawai dipengaruhi oleh motivasi, diantaranya yakni penelitian Rego, Supartha, dan Yasa (2017) mengungkapkan bahwa motivasi kerja juga akan mampu mempengaruhi dan meningkatkan kinerja pegawai. Artinya dengan memiliki motivasi kerja yang tinggi akan mampu memberikan hasil kerja yang maksimal. Selain berpengaruh terhadap motivasi kerja, gaya kepemimpinan yang tidak sesuai dengan pegawai juga dapat berdampak pada rendahnya disiplin kerja pegawai dalam melaksanakan tugas pokok dan fungsinya. Beberapa penelitian yang telah dilakukan sebelum juga mengungkapkan jika gaya kepemimpinan mampu mempengaruhi disiplin kerja pegawai, diantaranya yaitu penelitian Rosanti dan Nuzulia (2012), Mahdelena, Pangestoeti, dan Setiawan (2015), dan Ariani (2015), dimana gaya kepemimpinan berpengaruh positif dan signifikan terhadap disiplin kerja.

Disiplin merupakan perilaku positif yang intinya berupa sikap, tingkah laku dan perbuatan yang sesuai dengan peraturan yang berlaku, baik tertulis maupun tidak tertulis (Nitisemito dalam Ariani, N, 2015). Dalam suatu organisasi disiplin merupakan faktor yang sangat penting dalam rangka mewujudkan tujuan-tujuannya, karena tanpa kondisi disiplin baik suatu organisasi tak mungkin dapat mencapai hasil kinerja optimal. Beberapa penelitian yang telah dilakukan sebelumnya juga mencatat bahwa disiplin berpengaruh secara signifikan terhadap kinerja. Diantaranya yaitu penelitian Widodo, Alamsyah, dan Utomo (2018), yang menyatakan bahwa bahwa disiplin (Penggunaan waktu secara efektif, Ketaatan terhadap peraturan yang telah ditetapkan, serta datang dan pulang tepat waktu) berpengaruh terhadap kinerja sumber daya manusia artinya makin baik disiplin akan meningkatkan kinerja sumber daya manusia. Berangkat dari fenomena yang telah dikemukakan, maka peneliti memandang perlu adanya suatu kajian empirik yang mengungkapkan pengaruh variabel gaya kepemimpinan, terhadap disiplin kerja dan motivasi kerja serta dampaknya terhadap kinerja. Tujuan dari peneltian ini yaitu "untuk memperoleh gambaran gaya kepemimpinan, motivasi, disiplin, dan kinerja pegawai pada Dinas Pekerjaan Umum dan Perumahan Rakyat Provinsi Jambi; untuk mengetahui dan menganalisis pengaruh gaya kepemimpinan terhadap motivasi kerja, disiplin kerja, dan kinerja secara parsial; serta untuk mengetahui dan menganalisis pengaruh motivasi dan disiplin kerja terhadap kinerja pegawai baik secara parsial maupun secara simultan.”

\section{Landasan Teori}

\section{Gaya Kepemimpinan}

Menurut Thoha (2015) gaya kepemimpinan merupakan norma perilaku yang digunakan oleh seseorang pada saat orang tersebut mencoba mempengaruhi perilaku orang lain seperti yang ia lihat. Dalam hal ini usaha menyelaraskan persepsi di antara orang yang akan mempengaruhi perilaku dengan orang yang perilakunya akan dipengaruhi menjadi amat penting kedudukannya. Selain itu Priansa dan Somad (2012) menjelaskan bahwa gaya kepemimpinan adalah sikap, gerak-gerik, atau penampilan yang dipilih pemimpin dalam melaksanakan tugas kepemimpinannya. Gaya yang dipakai oleh seorang pemimpin satu dengan yang lainnya berbeda, tergantung pada situasi dan kondisi kepemimpinannya. Gaya kepemimpinan merupakan norma perilaku yang dipergunakan seseorang pada saat orang tersebut mencoba mempengaruhi perilaku yang konsisten yang ditunjukkan oleh pemimpin dan diketahui pihak lain ketika pemimpin berusaha mempengaruhi kegiatan-kegiatan orang lain. Menurut Pasolong dalam Ariani (2015) gaya kepemimpinan dapat diukur melalui: 1) Keputusan dibuat bersama; 2) Menghargai potensi setiap bawahannya; 3) Mendengar kritik, saran/pendapat dari bawahan; dan 4) Melakukan kerjasama dengan bawahannya.

\section{Motivasi Kerja}

Luthan (2009) mengemukakan bahwa motivasi adalah proses yang dimulai dengan defisiensi fisiologis atau psikologis yang menggerakan perilaku atau dorongan yang ditujukan untuk tujuan atau insentif. Dengan demikian, kunci untuk memahami proses motivasi bergantung pada pengertian dan hubungan antara kebutuhan, dorongan dan insentif. Kemudian Sutrisno (2009) juga menjelaskan motivasi adalah sesuatu yang menimbulkan semangat atau dorongan kerja. Motivasi adalah pemberian daya penggerak yang menciptakan kegairahan kerja seseorang, agar mereka mau bekerja sama, bekerja efektif, dan terintegrasi dengan segala daya upayanya untuk mencapai kepuasan. Selain itu Robbin dan Judge (2015) mendefinisikan motivasi sebagai proses yang menjelaskan mengenai kekuatan, arah, dan ketekunan seseorang dalam upaya untuk mencapai tujuan. Oleh karena motivasi secara umum adalah berkaitan dengan 
upaya menuju setiap tujuan, kita kan mempersempit fokus menjadi tujuan organisasi terhadap perilaku terkait pekerjaan. Menurut teori dua faktor yang dikembangkan oleh Hezberg, motivasi pada dasarnya dibagi atas dua faktor yaitu instrinsik dan ekstrinsik (Robbin dan Judge, 2015). Di mana faktor instrinsik dihubungkan dengan dengan kepuasan kerja, sementara faktor ekstrinsik dikaitkan dengan ketidakpuasan. Artinya, dorongan dalam diri seseorang untuk melakukan sesuatu itu muncul karena ada faktor-faktor instrinsik. Sementara yang berkaitan dengan pemenuhan kepuasan diri disebut faktor ekstrinsik.

\section{Disiplin Kerja}

Disiplin adalah kondisi kendali diri karyawan dan prilaku tertib yang menunjukkan tingkat kerjasama tim yang sesungguhnya dalam suatu organisasi. Salah satu aspek hubungan internal kekaryawanan yang penting namun sering kali sulit dilaksanakan adalah penerapan tindakan disipliner Mondy (2010). Siagian (2012) menyatakan bahwa disiplin kerja adalah sikap mental yang tercermin dalam perbuatan atau tingkah laku seseorang, kelompok masyarakat berupa ketaatan (obedience) terhadap peraturan, norma yang berlakudalam masyarakat. Menurut Handoko (2011) disiplin diartikan sebagai suatu keadaan tertib di mana orang-orang tergabung dalam organisasi tunduk pada peraturan yang telah ditetapkan dengan senang hati orang/sekelompok orang. Kedisiplinan adalah kesadaran dan ketaatan seseorang terhadap peraturan perusahaan/lembaga dan norma sosial yang berlaku. Lebih lanjut Handoko (2011) juga mengemukakan jika disiplin kerja pegawai dapat diukur melalui: 1) Ketepatan waktu; 2) menggunakan peralatan kantor dengan baik; 3) tanggungg jawab yang tinggi; dan 4) ketaatan terhadap aturan kantor.

\section{Kinerja}

Kinerja adalah suatu hasil kerja yang dicapai seseorang dalam melaksanakan tugas-tugas yang dibebankan kepadanya yang didasarkan atas kecakapan, pengalaman, kesungguhan serta waktu (Hasibuan, 2009). Menurut Gomes (2009) mendefinisikan kinerja adalah unjuk kerja yang merupakan hasil dari kerja yang dihasilkan oleh pegawai atau prilaku nyata yang ditampilkan sesuai dengan perannya dalam organisasi. Sedangkan menurut Sedarmayanti (2011) kinerja merupakan memenuhi atau menjalankan kewajiban suatu nazar, hasil para pekerja, proses organisasi, terbukti secara konkrit, menyempurnakan tanggung jawab, dapat diukur, dapat dibandingkan dengan standar yang sudah ditentukan. Selain itu Mangkunegara (2012) menjelaskan bahwa kinerja adalah hasil kerja secara kualitas dan kuantitas yang dicapai oleh seorang pegawai dalam melaksanakan tugasnya sesuai dengan tanggung jawab yang diberikan kepadanya. Lebih lanjut Mangkunegara (2012) mengemukakan bahwa kinerja pegawai dapat dinilai dari : 1) kualitas kerja; 2) kuantitas kerja; 3) tanggun jawab; 4) kerjasama; dan 5) inisiatif.

\section{Hipotesis}

Berdasarkan tujuan penelitian dan beberapa asumsi yang telah dikemukakan terdahulu dapat dirumuskan hipotesis yang merupakan dugaan sementara. Penulis merumuskan hipotesis berkenaan dengan masalah yang diteliti sebagai berikut:

1. Gaya kepemimpinan, motivasi kerja, disiplin kerja, dan kinerja pegawai pada Dinas Pekerjaan Umum dan Perumahan Rakyat Provinsi Jambi dalam kondisi baik.

2. Gaya kepemimpinan berpengaruh signifikan terhadap motivasi kerja.

3. Gaya kepemimpinan berpengaruh signifikan terhadap disiplin kerja.

4. Gaya kepemimpinan berpengaruh signifikan terhadap kinerja pegawai.

5. Motivasi dan disiplin secara simultan berpengaruh signifikan terhadap kinerja pegawai.

6. Motivasi dan disiplin secara parsial berpengaruh signifikan terhadap kinerja pegawai.

\section{METODE}

Berdasarkan tujuan penelitian maka jenis penelitian yang digunakan adalah explanatory research (penelitian penjelasan). Explanatory research merupakan penelitian yang dilakukan untuk menjelaskan hubungan kausal antara variabel-variabel penelitian melalui pengujian hipotesis (Singarimbun dan Effendi, 2012). Pendekatan penelitian yang digunakan dalam penelitian ini adalah pendekatan kuantitatif. Metode penelitian kuantitatif dapat diartikan sebagai metode penelitian yang berlandaskan pada filsafat positivism, 
digunakan untuk meneliti pada populasi atau sampel tertentu, teknik pengambilan sampel pada umumnya dilakukan secara random, pengumpulan data menggunakan instrument penelitian, analisis data bersifat kuantitatif/statistik dengan tujuan untuk menguji hipotesis yang telah ditetapkan (Sugiyono, 2012). Agar penelitian ini lebih terarah serta sesuai dengan tujuan yang diinginkan, data dan fakta dari angket yang terkumpul akan diuji dengan teknik analisis jalur (Path Analysis). Populasi dalam penelitian ini adalah pegawai Dinas Pekerjaan Umum dan Perumahan Rakyat Provinsi Jambi yang berjumlah 286 orang pegawai. Ukuran atau jumlah sampel dalam penelitian ini ditentukan berdasarkan teori yang dikembangkan oleh Slovin dengan nilai. Berdasarkan rumus penentuan jumlah sampel dari Slovin di atas didapat jumlah sampelnya (n) sebanyak 74,09 di bulatkan menjadi 75. Sedangkan teknik pengambilan sampelnya dilakukan secara acak atau menggunakan teknik random sampling untuk menentukan pegawai yang menjadi anggota sampel.

Analisis deskriptif digunakan dengan menyusun tabel frekuensi distribusi untuk mengetahui apakah tingkat perolehan nilai (skor) variabel penelitian masuk dalam katagori: sangat setuju, setuju, cukup setuju, tidak setuju, sangat tidak setuju. Dengan menggunakan alat ukur ini, maka nilai variabel yang diukur dengan menggunakan instrument tertentu dapat dinyatakan dalam bentuk angka, sehingga akan lebih akurat, efesien dan komunikatif. Langkah awal untuk menganalisa data dalam penelitian ini adalah menghitung skor-skor dari setiap butir soal kemudian skor-skor tersebut dijumlahkan untuk mendapatkan skor total. Umar (2012) Perhitung skor setiap komponen yg diteliti dengan mengalikan seluruh frekuensi data.

\section{Path Analysis}

Penelitian ini menggunakan analisis analisis jalur (Path Analysis). Analisis ini merupakan salah satu pilihan dalam rangka mempelajari ketergantungan sejumlah variabel didalam model. Analisis ini merupakan metode yang baik untuk menerangkan apabila terdapat seperangkat data yang besar untuk dianalisis dan mencari hubungan kausal (Ghozali, 2012). Analisis jalur (Path Analysis) dikembangkan sebagai metode untuk mempelajari pengaruh atau efek secara langsung dan tidak langsung dari variabel bebas terhadap variabel terikat. Analisis ini merupakan salah satu pilihan dalam rangka mempelajari ketergantungan sejumlah variabel didalam model. Analisis ini merupakan metode yang baik untuk menerangkan apabila terdapat seperangkat data yang besar untuk dianalisis dan mencari hubungan kausal (Ghozali, 2012). Lebih lanjut Ghozali (2012) mengemukakan besarnya pengaruh langsung dari suatu variabel eksogenus terhadap variabel endogenus tertentu, dinyatakan oleh besarnya nilai numeric koefisien jalur (path coefficient) dari eksogenus ke endogenus.

\section{Uji Hipotesis \\ Koefisien Determinasi $\left(R^{2}\right)$}

Koefisien Determinasi (KD) pada intinya mengukur seberapa jauh kemampuan model dalam menerangkan variasi variabel terikat. Nilai koefisien determinasi adalah dari nol (0) dan satu (1), nilai $\mathrm{R}^{2}$ yang kecil berarti kemampuan variabel-variabel independent dalam menjelaskan variasi variabel dependent amat terbatas. Nilai yang mendekati satu berarti variabel-variabel independent memberikan hampir semua informasi yang dibutuhkan untuk memprediksikan variasi variabel dependent. Analisis koefisien determinasi digunakan untuk melihat seberapa besar variabel independent $(\mathrm{X})$ berpengaruh terhadap variabel dependent (Y) yang dinyatakan dalam persentase.

\section{Uji F (Simultan)}

Uji F dilakukan untuk melihat apakah model regresi dapat digunakan untuk memprediksi variabel dependen. Tingkat probabilitas $<0,05$ dianggap signifikan atau model regresi tersebut dapat digunakan untuk memprediksi variabel dependen (Ghozali, 2012). Adapun kriteria pengujian hipotesis pada tingkat signifikansi $0,05(5 \%)$ sebagai berikut: Apabila $\mathrm{F}_{\text {hitung }}>\mathrm{F}_{\text {tabel }}$ atau alpha $<0.05$, maka tolak $\mathrm{H}_{0}$ dan terima $\mathrm{H}_{1}$; Apabila $\mathrm{F}_{\text {hitung }}<\mathrm{F}_{\text {tabel }}$ atau alpha $>0.05$, maka terima $\mathrm{H}_{0}$ dan tolak $\mathrm{H}_{1}$ 
Rizki Ananda et al, Pengaruh Gaya Kepemimpinan Terhadap Kinerja Pegawai dengan Motivasi dan Disiplin Kerja Sebagai Variabel Intervening Pada Dinas Pekerjaan Umum dan Perumahan Rakyat Provinsi Jambi

\section{Uji t (Parsial)}

Pengujian ini bertujuan untuk menguji apakah masing-masing variabel bebas berpengaruh secara signifikan terhadap variabel terikat secara parsial dengan $\alpha=0,05$ dan juga penerimaan atau penolakan hipotesis. Adapun kriteria dari pengujian hipotesis secara parsial pada tingkat signifikansi 0,05 (5\%) adalah sebagai berikut: Apabila thitung $>\mathrm{t}_{\text {tabel }}$ atau alpha $<0.05$, maka tolak $\mathrm{H}_{0}$ dan terima $\mathrm{H}_{1}$; Apabila $\mathrm{t}_{\text {hitung }}<\mathrm{t}_{\text {tabel }}$ atau alpha $>0.05$, maka terima $\mathrm{H}_{0}$ dan tolak $\mathrm{H}_{1}$

\section{HASIL}

\section{Deskripsi Data Variabel Gaya Kepemimpinan (X)}

Hasil deskriptif variabel gaya kepemimpinan diperoleh total skor sebesar 2.533, apabila dilihat dari rentang skala variabel gaya kepemimpinan termasuk pada range $1.950-2.549,9$ berada pada Kriteria Cukup Baik. Hal ini menunjukan bahwasanya gaya kepemimpinan yang ada pada Dinas Pekerjaan Umum dan Perumahan Rakyat Provinsi Jambi di kategorikan cukup baik.

\section{Deskripsi Data Motivasi Kerja $\left(Y_{1}\right)$}

Hasil deskriptif variable motivasi kerja diperoleh total skor sebesar 2.996, apabila dilihat dari rentang skala variabel motivasi termasuk pada range 2.340 - 3.059,9 berada pada Kriteria Cukup Tinggi. Hal ini menunjukan bahwasanya motivasi kerja pegawai pada Dinas Pekerjaan Umum dan Perumahan Rakyat Provinsi Jambi memiliki motivasi kerja yang cukup tinggi dalam melaksanakan tugas pokok dan fungsinya.

\section{Deskripsi Data Variabel Disiplin Kerja $\left(\mathrm{Y}_{2}\right)$.}

Hasil deskriptif variabel disiplin kerja diperoleh total skor sebesar 3.231, apabila dilihat dari rentang skala, variabel disiplin kerja termasuk pada range 3.060 - 3.779,9 berada pada Kriteria Tinggi. Artinya disiplin kerja pegawai pada Dinas Pekerjaan Umum dan Perumahan Rakyat Provinsi Jambi memiliki disiplin kerja yang tinggi.

\section{Deskripsi Data Variabel Kerja (Z).}

Hasil deskriptif variabel kinerja diperoleh total skor sebesar 3.990, apabila dilihat dari rentang skala, variabel kinerja termasuk pada range 3.825 - 4.824,9 berada pada Kriteria baik. Hal ini menunjukan bahwasanya pegawai telah mampu memberikan hasil kerja yang baik bagi organisasi tempat mereka bernaung.

\section{Path Analisis}

Untuk menjawab tujuan-tujuan dalam penelitian ini, struktur utama dalam model penelitian di pecah menjadi empat sub struktur. Dimana untuk menjawab hipotesis 2 dengan sub struktur pertama, untuk menjawab hipotesis 3 dengan menggunakan sub struktur kedua, untuk menjawab hipotesis 4 dengan menggunakan sub struktur ketiga, dan untuk menjawab hipotesis 5 dan 6 menggunakan sub struktur keempat. Berikut ini merupakan output SPSS dari empat struktur yang dirangkum pada tabel berikut.

Tabel 1

Output SPSS Dua Sub Struktur.

\begin{tabular}{|c|c|c|c|c|c|c|}
\hline \multirow{2}{*}{ Model } & \multicolumn{2}{|c|}{ Unstandardized Coefficients } & \multirow{2}{*}{ Beta } & \multirow{2}{*}{$\mathrm{t}$} & \multirow{2}{*}{$\mathrm{F}$} & \multirow{2}{*}{ Sig } \\
\hline & B & Std.Error & & & & \\
\hline $\mathrm{X}-\mathrm{Y}_{1}$ & 0,691 & 0,097 & 0,642 & 7,154 & - & 0,000 \\
\hline $\mathrm{X}-\mathrm{Y}_{2}$ & 0,773 & 0,080 & 0,750 & 9,685 & - & 0,000 \\
\hline $\mathrm{X}-\mathrm{Z}$ & 1,080 & 0,076 & 0,857 & 14,235 & - & 0,000 \\
\hline $\mathrm{Y}_{1}-\mathrm{Z}$ & 0,306 & 0,143 & 0,262 & 2,138 & - & 0,036 \\
\hline $\mathrm{Y}_{2}-\mathrm{Z}$ & 0,682 & 0,150 & 0,558 & 4,554 & - & 0,000 \\
\hline$Y_{1}$ dan $Y_{2}-Z$ & - & - & - & - & 57,396 & 0,000 \\
\hline
\end{tabular}

Hasil output diatas di masukkan ke dalam gambar persamaan struktural sebagai berikut: 
Rizki Ananda et al, Pengaruh Gaya Kepemimpinan Terhadap Kinerja Pegawai dengan Motivasi dan Disiplin Kerja Sebagai

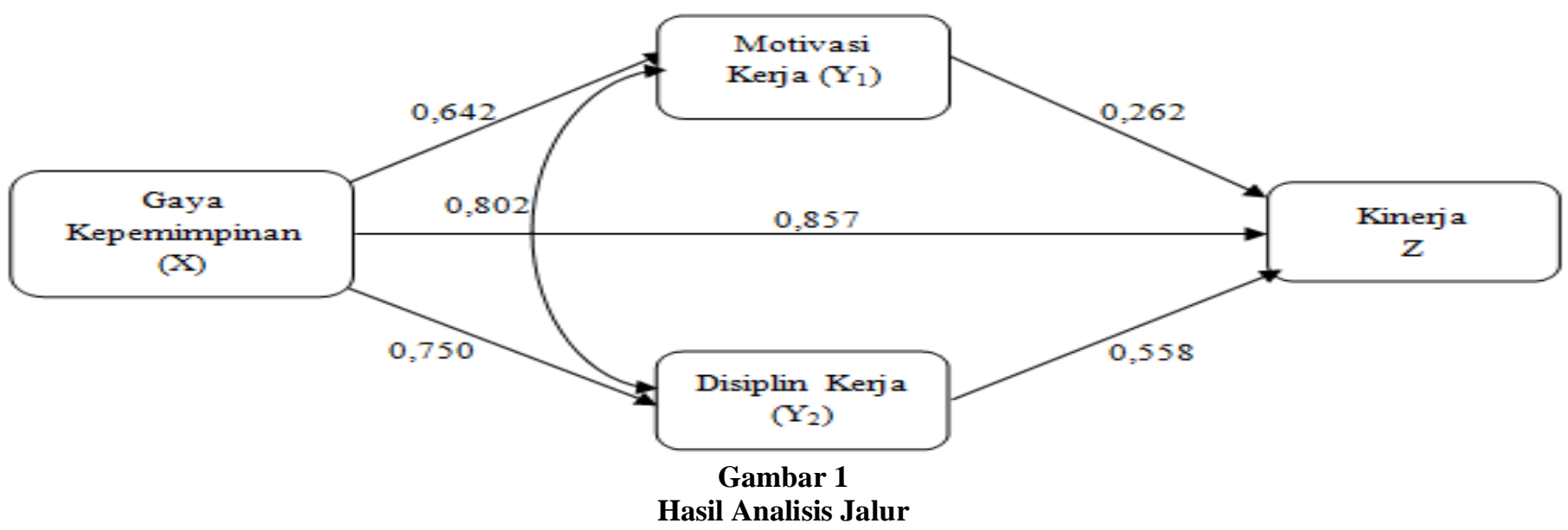

Untuk melihat pengaruh langsung dan tidak langsung, dapat dilihat pada Tabel 2 berikut:

Tabel 2

Rangkuman Koefisien Jalur Motivasi Kerja dan Disiplin Kerja Terhadap Kinerja

\begin{tabular}{|c|c|c|c|c|c|}
\hline \multirow{2}{*}{ Variabel } & \multirow{2}{*}{ Langsung } & \multicolumn{2}{|c|}{ Tidak Langsung } & \multirow{2}{*}{ Sub Total } & \multirow{2}{*}{ Total } \\
\hline & & $\mathrm{Y}_{1}$ & $\mathrm{Y}_{2}$ & & \\
\hline Motivasi $\left(\mathrm{Y}_{1}\right)$ & $6,86 \%$ & - & $11,73 \%$ & $11,73 \%$ & $18,59 \%$ \\
\hline Disiplin Kerja $\left(\mathrm{Y}_{2}\right)$ & $31,14 \%$ & $11,73 \%$ & - & $11,73 \%$ & $42,87 \%$ \\
\hline Pengaruh $\mathrm{Y}_{1}, \mathrm{Y}_{2}$ & & & & & $61,46 \%$ \\
\hline Pengaruh variabel lain & & & & & $38,54 \%$ \\
\hline
\end{tabular}

Sumber: Data olahan

Hasil analisis jalur yang dilakukan diperoleh pengaruh langsung motivasi terhadap kinerja sebesar $6,86 \%$, disiplin kerja terhadap kinerja sebesar $31,14 \%$ dan total pengaruh motivasi dan disiplin kerja terhadap kinerja secara langsung maupun tidak langsung sebesar 61,46. Nilai tersebut menjelaskan nilai koefisien determinasi $\mathrm{R}^{2}$ Square Seperti yang tampak pada tabel berikut.

Tabel 3

Koefisien Determinasi

\begin{tabular}{|l|r|r|r|r|}
\hline \multicolumn{1}{|c|}{ Model } & $\mathrm{R}$ & R Square & Adjusted R Square & Std. Error of the Estimate \\
\hline 1 &, $784^{\mathrm{a}}$ &, 615 &, 604 & 3,2726 \\
\hline
\end{tabular}

Sumber: Data olahan

Nilai R sebesar 0,784 menunjukan korelasi ganda (motivasi kerja dan disiplin kerja) dengan kinerja. Dengan mempertimbangkan variasi Nilai $R$ Square sebesar 0,615 yang menunjukan besarnya peran atau kontribusi variabel motivasi kerja dan disiplin kerja mampu menjelaskan variabel kinerja sebesar 61,5\% dan sisanya 38,5\% dipengaruhi oleh variabel lain yang tidak termasuk dalam model ini.

\section{Uji Hipotesis}

Pengaruh Gaya Kepemimpinan Terhadap Motivasi Kerja.

Hasil pengujian pada seperti yang dirangkum pada Tabel 1 diperoleh angka nilai $t$ hitung variabel gaya kepemimpinan sebesar 7.154, dengan nilai signifikansi sebesar 0,000, dikarenakan angka taraf signifikansi lebih $<0.05(0.000<0.05)$ maka dapat disimpulkan bahwa gaya kepemimpinan berpengaruh terhadap motivasi kerja pegawai. Berdasarkan dari penjelasan tersebut oleh karena itu $\mathrm{H}_{0}$ ditolak dan $\mathrm{H}_{1}$ diterima, artinya gaya kepemimpinan secara langsung berpengaruh terhadap motivasi kerja pegawai. Hasil penelitian ini sejalan dengan penelitian Fitriani dan Mane (2016), Nanda dan Wikansari (2017), dan Rego, Supartha dan Yasa (2017), dimana Gaya kepemimpinan berpengaruh positif dan signifikan terhadap motivasi kerja. Dalam sebuah organisasi bawahan bekerja selalu tergantung pada pimpinan. Bila pimpinan tidak memiliki kemampuan memimpin, maka tugas-tugas yang sangat kompleks tidak dapat dikerjakan dengan baik. Kepemimpinan didefinisikan sebagai kemampuan menggunakan pengaruh dan memotivasi 
Rizki Ananda et al, Pengaruh Gaya Kepemimpinan Terhadap Kinerja Pegawai dengan Motivasi dan Disiplin Kerja Sebagai Variabel Intervening Pada Dinas Pekerjaan Umum dan Perumahan Rakyat Provinsi Jambi

individu untuk mencapai tujuan organisasi (Gibson et.al 2010). Kemampuan mempengaruhi akan menentukan cara yang digunakan pegawai dalam mencapai hasil kerja. Hal ini didasari pada argumen bahwa seorang pemimpin memiliki otoritas dalam merencanakan, mengarahkan, mengkoordinasikan, dan mengawasi perilaku pegawai. Pemimpin organisasi dapat mempengaruhi perilaku dengan cara menciptakan sistem dan proses organisasi yang sesuai kebutuhan, baik kebutuhan individu, kebutuhan kelompok maupun kebutuhan organisasi.

\section{Pengaruh Gaya Kepemimpinan Terhadap Disiplin Kerja}

Hasil pengujian pada seperti yang dirangkum pada Tabel 1 diperoleh angka nilai t hitung variabel gaya kepemimpinan sebesar 9.685, dengan nilai signifikansi sebesar 0,000, dikarenakan angka taraf signifikansi lebih < $0.05(0.000<0.05)$ maka dapat disimpulkan bahwa gaya kepemimpinan berpengaruh terhadap disiplin kerja pegawai. Berdasarkan dari penjelasan tersebut oleh karena itu $\mathrm{H}_{0}$ ditolak dan $\mathrm{H}_{1}$ diterima, artinya gaya kepemimpinan secara langsung berpengaruh terhadap disiplin kerja pegawai. Beberapa penelitian yang telah dilakukan sebelum juga mengungkapkan jika gaya kepemimpinan mampu mempengaruhi disiplin kerja pegawai, diantaranya yaitu penelitian Rosanti dan Nuzulia (2012), Mahdelena, Pangestoeti, dan Setiawan (2015), dan Ariani (2015), dimana gaya kepemimpinan demokratis berpengaruh positif dan signifikan terhadap disiplin kerja. Dalam organisasi, faktor kepemimpinan memegang peranan yang sangat penting karena pemimpin itulah yang akan menggerakkan dan mengarahkan organisasi dalam mencapai tujuan. Gaya kepemimpinan yang dilakukan oleh pemimpin berpengaruh terhadap tingkat disiplin kerja karyawan atau bawahannya. Oleh karena itu, dibutuhkan seorang pemimpin yang baik yang bertanggungjawab pada bawahannya untuk meningkatkan semangat kerja dan disiplin kerja bawahannya dalam melaksanakan tugas yang diberikan (Rosanti dan Nuzulia, 2012).

\section{Pengaruh Gaya Kepemimpinan Terhadap Kinerja}

Hasil pengujian pada seperti yang dirangkum pada Tabel 1 diperoleh angka nilai t hitung variabel gaya kepemimpinan sebesar 14.235, dengan nilai signifikansi sebesar 0,000, dikarenakan angka taraf signifikansi lebih $<0.05(0.000<0.05)$ maka dapat disimpulkan bahwa gaya kepemimpinan berpengaruh terhadap kinerja pegawai. Berdasarkan dari penjelasan tersebut oleh karena itu $\mathrm{H}_{0}$ ditolak dan $\mathrm{H}_{1}$ diterima, artinya gaya kepemimpinan secara langsung berpengaruh terhadap kinerja pegawai. Hasil penelitian ini sejalan dengan penelitian Widodo, Alamsyah, dan Utomo (2018), Mardiana (2014), Yugusna, Fathoni, Haryono (2016), dan Rego, Supartha, dan Yasa (2017) yang mengemukakan bahwa gaya kepemimpinan berpengaruh positif dan signifikan terhadap kinerja pegawai. Menurut Bass dalam Rego, Supartha, dan Yasa (2017) peran kepemimpinan dalam memberikan kontribusi pada karyawan untuk pencapaian kinerja yang optimal dilakukan melalui lima cara, yaitu: (1) pemimpin mengklasifikasikan apa yang diharapkan dari karyawannya, secara khusus tujuan dan sasaran dari kinerja mereka, (2) pemimpin menjelaskan bagaimana mmenuhi harapan tersebut, (3) pemimpin mengemukakan kriteria dalam melakukan evaluasi dari kinerja secara efektif, (4) pemimpin memberikan umpan balik ketika karyawan telah mencapai sasaran, dan (5) pemimpin mengalokasikan imbalan berdasarkan hasil yang telah mereka capai.

\section{Pengaruh Motivasi dan Disiplin Kerja Terhadap Kinerja Secara Simultan.}

Hasil uji Anova atau F test seperti yang tampak pada Tabel 1 dengan menggunakan SPSS 21.0 didapat $F_{\text {hitung }}$ sebesar 57,396 dengan tingkat probabilitas $p$-value sebesar 0,000, dikarenakan angka taraf signifikansi jauh lebih $<0.05(0.000<0.05)$ oleh karena itu berdasarkan penjelasan tersebut maka $\mathrm{H}_{0}$ ditolak dan $\mathrm{H}_{1}$ diterima, artinya hal ini membuktikan bahwa variabel motivasi dan disiplin kerja secara bersamasama berpengaruh secara signifikan terhadap variabel kinerja. Selain itu pula perhitungan nilai total pengaruh langsung dan tidak langsungmotivasi dan disiplin kerja secara bersama-sama terhadap kinerja sebesar $61,46 \%$, dimana angka tersebut menjelaskan bahwa secara langsung motivasi dan disiplin kerja memberikan kontribusi terhadap kinerja sebesar 61,46\%. Dimana nilai R sebesar 0,784 menunjukan korelasi ganda (motivasi kerja dan disiplin kerja) dengan kinerja. Dengan mempertimbangkan variasi Nilai R Square sebesar 0,615 yang menunjukan besarnya peran atau kontribusi variabel motivasi kerja dan disiplin kerja 
Rizki Ananda et al, Pengaruh Gaya Kepemimpinan Terhadap Kinerja Pegawai dengan Motivasi dan Disiplin Kerja Sebagai Variabel Intervening Pada Dinas Pekerjaan Umum dan Perumahan Rakyat Provinsi Jambi

mampu menjelaskan variabel kinerja sebesar 61,5\% dan sisanya 38,5\% dipengaruhi oleh variabel lain yang tidak termasuk dalam model ini.

\section{Pengaruh Motivasi dan Disiplin Kerja Terhadap Kinerja Secara Parsial. Pengaruh Motivasi Terhadap Kinerja}

Hasil pengujian pada seperti yang dirangkum pada Tabel 1 diperoleh angka nilai t hitung variabel motivasi kerja sebesar 8.604, dengan signifikansi sebesar 0,000, dikarenakan angka taraf signifikansi lebih $<0.05(0.000<0.05)$ maka dapat disimpulkan bahwa motivasi kerja berpengaruh terhadap kinerja pegawai. Berdasarkan dari penjelasan tersebut oleh karena itu $\mathrm{H}_{0}$ ditolak dan $\mathrm{H}_{1}$ diterima, artinya motivasi kerja secara langsung berpengaruh terhadap kinerja pegawai. Hasil penelitian ini sejalan dengan penelitian Rego, Supartha, dan Yasa (2017) mengungkapkan bahwa motivasi kerja juga akan mampu mempengaruhi dan meningkatkan kinerja pegawai. Artinya dengan memiliki motivasi kerja yang tinggi akan mampu memberikan hasil kerja yang maksimal. Motivasi kerja terbentuk dari sikap (attitude) individu dalam menghadapi situasi kerja (situation) di organisasi. Motivasi merupakan kondisi atau energy yang menggerakkan diri individu yang terarah atau tertuju untuk mencapai tujuan organisasi. Sikap mental pro dan positif terhadap situasi kerja tim itulah yang memperkuat motivasi kerjanya untuk mencapai kinerja maksimal (Mangkunegara, 2014).

\section{Pengaruh Disiplin Terhadap Kinerja}

Hasil pengujian pada seperti yang dirangkum pada Tabel 1 diperoleh angka nilai t hitung variabel disiplin kerja sebesar 10,251, dengan signifikansi sebesar 0,000, dikarenakan angka taraf signifikansi lebih < $0.05(0.000<0.05)$ maka dapat disimpulkan bahwa disiplin kerja berpengaruh terhadap kinerja pegawai. Berdasarkan dari penjelasan tersebut oleh karena itu $\mathrm{H}_{0}$ ditolak dan $\mathrm{H}_{1}$ diterima, artinya disiplin kerja secara langsung berpengaruh terhadap kinerja pegawai. Disiplin merupakan perilaku positif yang intinya berupa sikap, tingkah laku dan perbuatan yang sesuai dengan peraturan yang berlaku, baik tertulis maupun tidak tertulis (Nitisemito dalam Ariani, N, 2015). Dalam suatu organisasi disiplin merupakan faktor yang sangat penting dalam rangka mewujudkan tujuan-tujuannya, karena tanpa kondisi disiplin baik suatu organisasi tak mungkin dapat mencapai hasil kinerja optimal. Beberapa penelitian yang telah dilakukan sebelumnya juga mencatat bahwa disiplin berpengaruh secara signifikan terhadap kinerja. Diantaranya yaitu penelitian Widodo, Alamsyah, dan Utomo (2018), yang menyatakan bahwa bahwa Disiplin (Penggunaan waktu secara efektif, Ketaatan terhadap peraturan yang telah ditetapkan, serta datang dan pulang tepat waktu) berpengaruh terhadap kinerja sumber daya manusia artinya makin baik disiplin akan meningkatkan kinerja sumber daya manusia. Kedisiplinan merupakan suatu hal yang menjadi tolak ukur untuk mengetahui apakah peran pimpinan secara keseluruhan dapat dilaksanakan dengan baik atau tidak. Disiplin kerja adalah tindakan manajemen untuk menegakkan standar organisasi (Davis, 2009). Disiplin juga merupakan bentuk pengendalian diri karyawan dan pelaksanaan yang teratur menunjukkan tingkat kesungguhan tim kerja dalam sebuah organisasi, tindakan disiplin menuntut adanya hukuman terhadap karyawan yang gagal memenuhi standar yang ditentukan. Oleh karena itu tindakan disiplin tidak diterapkan secara sembarangan, melainkan memerlukan pertimbangan bijak.

\section{SIMPULAN}

Berdasarkan hasil analisa data dan pembahasan dalam penelitian ini dapat disimpulkan bahwa:

a. Gaya kepemimpinan, motivasi, disiplin kerja dan kinerja pegawai pada Dinas Pekerjaan Umum dan Perumahan Rakyat Provinsi Jambi dalam kondisi yang cukup baik.

b. Gaya kepemimpinan berpengaruh positif dan signifikan terhadap motivasi kerja pegawai pada Dinas Pekerjaan Umum dan Perumahan Rakyat Provinsi Jambi.

c. Gaya kepemimpinan berpengaruh positif dan signifikan terhadap disiplin kerja pegawai pada Dinas Pekerjaan Umum dan Perumahan Rakyat Provinsi Jambi.

d. Gaya kepemimpinan berpengaruh positif dan signifikan terhadap kinerja pegawai pada Dinas Pekerjaan Umum dan Perumahan Rakyat Provinsi Jambi. 
Rizki Ananda et al, Pengaruh Gaya Kepemimpinan Terhadap Kinerja Pegawai dengan Motivasi dan Disiplin Kerja Sebagai Variabel Intervening Pada Dinas Pekerjaan Umum dan Perumahan Rakyat Provinsi Jambi

e. Motivasi dan disiplin kerja secara simultan berpengaruh positif dan signifikan terhadap kinerja pegawai pada Dinas Pekerjaan Umum dan Perumahan Rakyat Provinsi Jambi. Dimana total pengaruh langsung dan tidak langsung motivasi dan disiplin kerja secara bersama-sama terhadap kinerja sebesar 61,46\%.

f. Motivasi dan disiplin kerja secara parsial berpengaruh positif dan signifikan terhadap kinerja pegawai pada Dinas Pekerjaan Umum dan Perumahan Rakyat Provinsi Jambi.

\section{DAFTAR PUSTAKA}

Ariani, N. 2015. Pengaruh Gaya Kepemimpinan Demokratis terhadap Disiplin Kerja Karyawan Pada PT. PP. London Sumatra Indonesia, Tbk. Wilayah Bulukumba. Eprints Universitas Negeri Makasar.

Davis. 2009. Perilaku Dalam Organisasi, Edisi ketujuh. Jakarta: Penerbit Erlangga.

Fitriani, T., Idris, M., dan Mane, A.A. 2016. Pengaruh Gaya Kepemimpinan Terhadap Motivasi Kerja (Studi Kasus Badan Pemberdayaan Masyarakat Kab. Kepulauan Selayar. Jurnal Riset Edisi IV Unibos, Vol. 3, No. 5 .

Ghozali, I. 2012. Aplikasi Analisis Multivariate dengan Program SPSS Cetakan Pertama. Semarang: Badan Penerbit Universitas Diponegoro.

Gomes, F. C. 2009. Manajemen Sumber Daya Manusia. Yogyakarta: Penerbit Andi.

Gibson, J.L. 2010. Organisasi. Perilaku, Struktur dan Proses. Jakarta: Binarupa Aksara.

Handoko, T. H. 2011. Management Personalia dan Sumber Daya Manusia. Yogyakarta: BPFE

Hasibuan, M. S. P. 2010. Manajemen Sumber Daya Manusia. Jakarta: edisi Revisi, Penerbit: Bumi Aksara.

Luthan, F. 2009. Perilaku Organisasi. Yogyakarta: Andi.

Mahdelena., Pangestoeti, W., dan Setiawan, R. 2015. Hubungan Gaya Kepemimpinan Demokratis Terhadap Disiplin Pegawai Dinas Kependudukan dan Pencatatan Sipil Provinsi Kepulauan Riau. Naskah Publikasi Ilmu Sosial dan Ilmu Politik, Universitas Maritim Raja Ali Haji.

Mangkunegara, A. P. 2012. Evaluasi Kinerja Sumber Daya Manusia. edisi pertama, cetakan pertama. Bandung: Refika Aditama.

Mardiana. 2014. Pengaruh Gaya Kepemimpinan Demokratis Terhadap Kinerja Pegawai pada Kantor Sekretariat Daerah Kota Samarinda. eJournal Ilmu Pemerintahan, Vol. 2, No 1.

Mondy,R.W. 2010. Indocitra Humas Resource Mangement. $11^{\text {th }}$ Edition. New Jersey: Pearson Education

Nanda, D.A., dan Wikansari, R. 2017. Pengaruh Gaya Kepemimpinan Demokratis Terhadap Motivasi Kerja Karyawan Pada PT. XYZ. Jurnal Aplikasi Manajemen Ekonomi dan Bisnis, Vol. 2, No. 1.

Priansa, D.J., dan Somad, R. 2012. Manajemen Supervisi \& Kepemimpinan Kepala Sekolah. Bandung: Alfabeta

Rego, E.B.D., Supartha, W.G., dan Yasa, N.N.K. 2017. Pengaruh Kepemimpinan Terhadap Motivasi dan Kinerja Karyawan pada Direktorat Administrasi dan Keuangan, Kementerian Estatal Timor Leste. EJurnal Ekonomi dan Bisnis Universitas Udayana. Vol. 6, No. 11.

Robbins, S.P \& Judge, T.A. 2015. Perilaku Organisasi. Jakarta: PT. Salemba Empat.

Rosanti, A., dan Nuzulia, S. 2012. Pengaruh Gaya Kepemimpinan Demokratis Atasan Terhadap Disiplin Kerja Pegawai. Intuisi Jurnal Psikologi Ilmiah, Vol. 4, No. 1.

Sedarmayanti. 2011. Sumber Daya Manusia dan Produktivitas Kerja. Bandung: Mandar Maju.

Siagian, S. 2012. Manajemen Sumber Daya Manusia (cetakan 15). Jakarta: Bumi Aksara.

Singarimbun, M dan Effendi, S. 2012. Metode Penelitian Survey. Jakarta: LP3AES.

Sugiyono. 2012. Metode Penelitian Bisnis. Bandung: CV. Alfabeta.

Sutrisno, E. 2009. Manajemen Sumber Daya Manusia. Jakata: Kencana Prenada Media Group.

Terry, G.R., dan Rue, L.W. 2010. Dasar-Dasar Manajemen. Jakarta: Bumi Aksara.

Thoha, M. 2015. Kepemimpinan dalam Manajemen. Jakarta: Rajawali Pres.

Umar, H. 2012. Metode Penelitian untuk Skripsi dan Tesis Bisnis. Jakarta: Raja Grafindo.

Widodo, T., Alamsyah, N., dan Utomo, C.B. 2018. Analisis Pengaruh Gaya Kepemimpinan, Disiplin Kerja, dan Pelatihan Kerja Terhadap Kinerja Karyawan di PT. Telkom Indonesia Cabang Batam. Jurnal Industri Kreatif (JIK), Vol. 2, No. 1. 
Rizki Ananda et al, Pengaruh Gaya Kepemimpinan Terhadap Kinerja Pegawai dengan Motivasi dan Disiplin Kerja Sebagai Variabel Intervening Pada Dinas Pekerjaan Umum dan Perumahan Rakyat Provinsi Jambi

Yugusna, I., Fathoni, A., Haryono, A.T. 2016. Pengaruh Gaya Kepemimpinan Demokratis dan Lingkungan Kerja Terhadap Kinerja dan Kedisiplinan Karyawan (Studi Empiris Pada Perusahaan SPBU 44.501.29 Randu Garut Semarang). Journal Of Management, Volume 2, No. 2. 